\title{
EPilogue: NeW York
}

Much of Kitty Marion's energy between 1933 and 1938 was spent trying to interest publishers in her autobiography. In August 1933, Olive Johnson, secretary of the Birth Control Information Centre in London, was writing to Marion congratulating her on finishing her book. By 1934 she is commiserating with her on its rejection and hoping 'that the new man will be kinder' (5 January 1934, KMP: II/1). Attempts were made in England and America to find a sympathetic publisher; then in 1936 Anna Askanasy organised the typing of the manuscript. The following year, the German translation of the autobiography was, apparently, being considered by an Austrian publisher, and an article on Marion's 'life story' by Dr Irma Hift-Schnierer was published in the liberal Viennese paper, Wochenausgabe. ${ }^{1}$ Askanasy was promoting publication as a 'valuable [contribution] for their feminist movement'. 'It should certainly inspire their efforts for women's suffrage', Johnson wrote to Marion (26 August 1937, KMP: II/1). Then, in Marion's words, 'Hitler butted in and scattered' the group (KM to AP, 5 December 1940 TWL: 6.1 Box 2). With the annexation of Austria and the death of her husband at the hands of the Nazis in 1938, Anna Askanasy fled to London and then went to Canada, ${ }^{2}$ destroying any hope of a German publication - and Marion appears to have given up any sustained attempt to have her work published, perhaps because by this date she was more concerned with simply living.

Her work with the Women's Peace Society having come to an end in 1934, Marion was almost destitute. In March 1935 she found herself 'interesting but strenuous' work which her friend Edith How-Martyn hoped would 'give [her] a fresh lease of life' (6 April 1935, KMP: II/1). This work was with the Works Progress Administration, which had been set up in 1935 as a unified relief project to address the problems of unemployment and poverty during the Depression as a key part of Franklin D. Roosevelt's 'New Deal' programme.

${ }^{1}$ Irma Hift-Schnierer (1893-1972), child psychologist, historian and journalist. 'Schreiberin um Frauenrechte. Lebensroman einer Suffragette' ('Writer on women's rights: life-story of a suffragette'), Wochenausgabe, 2 October 1937.

2 Anna Helene Askanasy/Aszkanazy (née Mahler - niece of Gustav Mahler - 1893-1970) and Simon Aszkanazy (1883-1938). The Aszkanazys were members of the Viennese intelligentsia, and great art collectors. Simon was a civil engineer and Anna was a writer and internationally active feminist with a passion for women's history. Simon became a member of the Austrian resistance and was murdered in the Vienna Detention Camp in March 1938, shortly after the Anschluss. Anna escaped to London with her daughters, Elizabeth and Clarisse, and from London went to Canada, where they settled, but not before Anna had returned to Europe to rescue other refugees including Meta Kraus-Fessel, who had translated KM's autobiography into German. 
An article in the New Yorker in July 1936, called 'Where Are They Now? The Crusader', having traced Marion after her disappearance from her Birth Control Review pitches around New York, details her recent history:

She lives alone in a single furnished room on the second floor of an old brownstone house at 230 West Twenty-second Street. Her dream is some day to have enough room and enough money to adopt five or six children. Kitty Marion turned sixty five just a little while ago. She is happier now than she has been for some time, because she is working again at something she really enjoys. A few years ago she had the good fortune to meet Miss Agnes V. Birmingham, who is assistant director of the Speech Improvement Project of the WPA.... When teachers were needed to correct the speech of children of foreign parents, Miss Birmingham recommended Miss Marion ... She has been teaching three days a week at P.S. $51^{3}$ and two days at P.S.32. During the summer, she has a job supervising children's recreation in the public parks four days a week. P.S.51 ... is in the Heart of Hell's Kitchen, and with the youngsters there Miss Marion has her troubles, but she doesn't mind. She has taught a lot of children from four to fifteen to say 'thirty-three' instead of 'tirty-tree' or 'toity-dree' or whatever they had been saying. A special problem was a little boy who couldn't pronounce 's' - he would say 'he mell moke' for 'she smell smoke' - but Miss Marion coaxed him out of it.

... She treats all her pupils as if they were future Presidents of the United States. When we asked her if that went for the little girls, too, Miss Marion was prompt in her reply. 'Certainly,' she said firmly. 'There will be a woman President some day. I think it will be a good thing.' (New Yorker, 4 July 1936: 22-4)

Unfortunately, by October 1936, Olive Johnson was writing to Marion:

I am sorry your own pleasant work has come to an end, and I hope you'll be successful in getting a transfer to the kind of work that particularly appeals to you. Just what is the 'Theatre Project'? Any way it is something to remain on the payroll these days, even if it isn't spiritually satisfying; though it is disappointing to be taken off work one feels is doing good. Is the 'Theatre Project' part of the educational system in the U.S.A.? (14 October 1936, KMP: II/1)

The Theatre Project was the Federal Theatre Project (FTP), another part of the WPA programme, which was designed to give unemployed theatre workers work in theatre and other performance-related activity. ${ }^{4}$ However, this work proved less congenial to Marion than teaching her project students 'how to speak', and appears to have involved 'investigating' rather than " drawing out of the children what they have to give." Marion saw the children 'as little plants developing daily leaf by leaf,' and had found it gave her 'quite a thrill ... also the children when they got their "s"ing "th", or whatever it was - right' (KM to AP, 5 December 1940, TWL: 6.1 Box 2). In November 1936, How-Martyn was hoping that 'the new job

${ }^{3}$ P.S.51 et al refers to 'Public School 51', in New York City.

${ }^{4}$ The FTP is best known for its pioneering community-based, agit-prop, Living Newspapers very different from the commercial music theatre Kitty Marion had done in Britain twenty years before. 
is turning out better than you expected', and a week later that 'the change in your work will turn out more happily than you expect. ... Your last note sounded a little depressed' (3 November and 8 November 1936, KMP: II/1). In the same month Johnson expresses similar concern but also refers to one of the first signs that Marion's health was deteriorating when she asks whether she is having hearing tests (5 November 1936, KMP: II/1). By January 1937 Johnson was writing: 'I am sorry you are being kept in a state of worry about the WPA and I do hope you will be one of the lucky ones who are kept on. The damned worry is much worse than hard work isn't it?' (20 January 1937, KMP: II/1).

Marion was kept on temporarily, with Johnson 'awfully sorry [she was] on such a tiring job' and hoping 'you'll be put on less physically exhausting work very quickly' (22 May 1937, KMP: II/1). In June 1937, Marion was finally 'dropped' when the programme went into liquidation, and worryingly, her health seems to have worsened. 'My poor dear, I am so sorry to hear about the arthritis,' Johnson wrote (ibid.). Marion had lost not just her job and income, but also her ability to pay for the medical treatment she had been receiving. She thought there was some possibility of receiving an old-age pension giving her 'enough to live simply'. When she was finally granted a pension in September 1937, she was able to resume medical treatment at St Vincent's Hospital, ${ }^{5}$ but she was clearly having trouble walking. Johnson wrote sympathetically that 'It is awful not to be able to use one's legs' (17 December 1937, KMP: II/1). Three years later, Marion's health was so bad that with the 'weather and my arthritis, I am like a rat in a trap', she wrote to Alice Park. 'I can hardly get across the room with the aid of two sticks. Going out in rain or snow, which latter has been falling all day, is out of the question' (5 December 1940. TWL: 6.1 Box 2).

Between 1938 and 1944, by which time Marion was living in the Sanger Nursing Home, we have little information. ${ }^{6}$ She did eventually meet Anna Askanasy in New York with her 'two darling daughters' in 1938, when they had a 'grand Kaffeeklatsch'7 (KM to How-Martyn, 10 December 1938, MLSC: 50.82/1122). Her last extant letter, to Alice Park, dated 20 May 1943, is from the address she had lived in for more than a decade, 230 W. 22nd Street, which is also the address given on the front page of the autobiography. The letter concludes, 'I am somewhat under the weather, cold and raining, simply miserable! Gives me the dithers!' (KM to AP, TWL: 6.1 Box 2). It is clear that Marion maintained her vigorous correspondence with her old suffrage comrades and American friends, particularly Alice Park, signing off affectionately 'with love' or, on one occasion, 'with affectionate, suffragetty love’ (KM to AP, 9 December 1942, TWL: 6.1 Box 2). They discuss

\footnotetext{
${ }^{5}$ St Vincent's Hospital, Manhattan (1849-2010), a Catholic charitable institution which provided medical care for the poor of New York City.

${ }^{6}$ Another omission might have been a marriage. The 1940 New York census gives her marital status as ' $M$ '. All previous documentation, passenger manifests, censuses etc., have her as single or 'Head', i.e. not a wife or widow. The editors assume the 1940 reference to be an error, as no mention of a 'husband' is made anywhere else.

${ }^{7}$ Kaffeeklatsch - coffee-gossip.
} 
feminist politics and the peace movement, and at times Marion reflects on earlier relationships. Of Sanger she writes that although she, Sanger, 'used to express her appreciation of Anna [Lifschitz] and me and say that neither should ever want for anything while she had anything ... she "wangled" us both out of the Birth Control Review organisation. (Sanger's marriage to the wealthy Noah Slee in 1922 would have made this a particularly sensitive area.) While she asks Park to 'Excuse me ranting on like this', Marion adds that 'when I think back, I could kick myself for being such a devoted idiot' (17 July 1942, TWL: 6.1 Box 2). Marion continued to read and clip the newspapers voraciously, sending them to Johnson at the Birth Control Worldwide News Service that she ran. She also wrote to the papers on all manner of subjects from the New Deal - 'the anti-New Dealers might be standing in the place of the millions of unemployed who, figuratively speaking, had fallen among thieves, been robbed of their jobs and left to die, until the Good Samaritan in the shape of the New Deal, CCC, ${ }^{8}$ WPA etc., came to bind their wounds and provide them with work and the barest necessities of life' (Unidentified cutting, KMP: III/2) - to Rosika Schwimmer's application for American citizenship and 'The Speech Menace'. To judge by one letter on the latter subject, Marion was also listening to the radio: "will someone please tell me if " $\mathrm{d}$ " is the correct American pronunciation of " $\mathrm{t}$ " when that letter appears in the middle or end of a word ... when such pronunciation comes from high school and college students, who take part in radio "quiz" programs ...' (City Worker 10 May 1939, KMP: III/2). And on another occasion, she reported with characteristic humour about having 'heard a funny one ... a little while ago. British women are [now] permitted to enter Churches and law courts without hats. What a concession to the Almighty, who created them hatless' (KM to AP, 9 December 1942, TWL: 6.1 Box 2). Marion also appears to have kept in contact with some of her project children. At her memorial supper 'a nine year old lad who she taught speech' spoke and said that he would miss her, not only because she had taught him his English diction, but because she had inspired him to be a stamp collector and he had received stamps from her from everywhere. ${ }^{9}$

Kitty Marion died on 9 October 1944, aged 73. She had been ill for some time and had been taken from St Vincent's Hospital to the Sanger Nursing Home, which was in a pleasant residential district just west of Central Park. Her fame was still sufficient for her to merit an obituary in the New York Herald Tribune and other papers. She left a will stipulating that there should be no funeral and that she was to be cremated without religious services or flowers. Her friends held a memorial celebration in November where her mementos were displayed and her 'diary' was read. Tributes came from all over America and the United Kingdom and from as far away as Jamaica and Australia.

8 The CCC, Civilian Conservation Corps, was part of Roosevelt's New Deal work relief programme, which gave young men work on environmental projects.

9 Account of KM’s memorial celebration, Kitty Marion Papers, KMP: III/2. 
Katherine C. Evans, ${ }^{10}$ a fellow suffragette from Scotland, read the following poetic 'Address to Kitty Marion':

Dear Kitty - You are Guest of Honour here

Honoured by all the friends that hold you dear:

Tho many of the ones who loved you well

Cannot be present, of your life to tell:

But some are here, to show in bright mosaic

The pattern of that life, never prosaic:

I can but tell them of your suffrage fame

In England where you boare [sic] a well known name:

How great your character was formed when young

To be heroic, O Amazon unsung.

The poetic tribute continues for six more verses, extolling Kitty Marion's suffrage activities, and ends, happily, with one of Kitty's own jokes:

But nothing robbed you of your sense of mirth Which popped up even about the control of birth

And twas your way when ending friends a letter

To make them laugh and feel a little better

I'll end by quoting one of recent date

Do you remember writing me "Dear Kate,

The Queen of bees is a busy soul

She doesn't believe in birth control

And this is the reason without a doubt

There are so many sons of B's about."

As Mrs Hazel Moore said, 'Kitty's gallant spirit is here - and goes marching on.'11

${ }^{10}$ Katherine C. Evans (n.d.). Probably Kate Evans, suffragette, political agent, poet, performer and correspondent of Marie Stuart de Baecker, a relative of Emily Wilding Davison, about whom Evans also wrote poetic tributes. (https://www.thehistorypress.co.uk/articles/tracingemily-wilding-davison-s-family-history. Accessed 20 February 2018).

${ }^{11}$ From the account of KM's memorial celebration, KMP: III/2. 